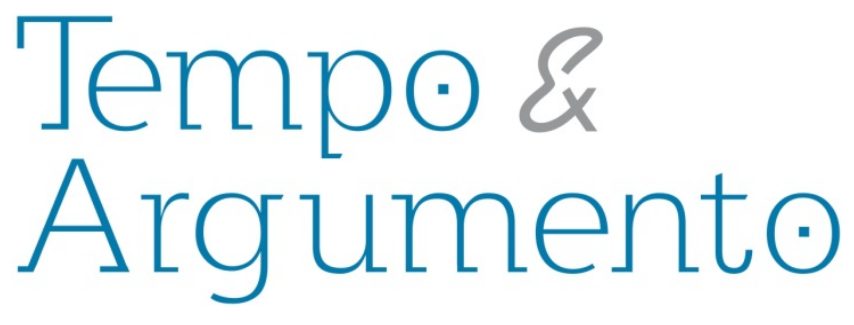

\title{
A transição democrática brasileira (1974-1989) pelas lentes de João Batista de Andrade
}

\begin{abstract}
Resumo
Este artigo aborda a relação entre memória e mídia, a partir do longa-metragem, de ficção, A Próxima Vítima (1983), de João Batista de Andrade, partindo da ideia de que um artefato cultural é um suporte de memória. Se um filme, mesmo de modo ficcional, encena aspectos do presente do período no qual é realizado, constitui registros que lhe conferem tal lugar de memória. O filme de Andrade, concebido no início dos anos 1980 e herdeiro da trajetória profissional do diretor, tanto no cinema quanto na televisão, entra nos embates de memória, como testemunho do período de transição democrática no Brasil (1974-1989), seja por sua datação, seja pelo que artificiosamente constrói. No texto, situamos, incialmente, questões que sobressaem na chave memória e mídia; em seguida, passamos pela cinematografia do cineasta, no que se conecta ao filme em questão; a chegada é o filme como memória da transição.
\end{abstract}

Palavras-chave: Cinema e História. Memória. Brasil-História1974-1989.

\section{Para citar este artigo:}

OLIVEIRA, Alcilene Cavalcante. A transição democrática brasileira (1974-1989) pelas lentes de João Batista de Andrade. Revista Tempo e Argumento, Florianópolis, v. 9, n. 21, p. 43 - 73.

maio/ago. 2017. 


\title{
The Brazilian democratic transition (1974-1989) through the lens of João Batista de Andrade
}

\begin{abstract}
This article approaches the relationship between memory and media, from the feature film, fiction, The Next Victim (1983), by João Batista de Andrade, starting from the idea that a cultural artifact is a support of memory. If a film, even fictionally, embodies aspects of the present from the period in which it is performed, it constitutes records that give it such a place of memory. Andrade's film, conceived in the early $1980 \mathrm{~s}$ and heir to the director's professional career, both in the cinema and on television, enters into the memories, as a testimony of the period of democratic transition in Brazil (1974-1989), or by his dating, or by what artificially builds. In the text, we put, initially, questions that stand out in the key memory and media; then we go through the cinematography of the film-maker, in what connects to the film in question; the arrival is the film as the memory of the transition.
\end{abstract}

Keywords: Cinema and History. Memory. Brazil-History-19741989.

\section{Primeiros passos: memória e mídia}

“Os meios de comunicação têm agora um monopólio sobre a história. Nas nossas sociedades contemporâneas, é por eles e por eles apenas que o evento nos atinge, e não podemos evitar" (NORA, 1972, p. 162, tradução nossa). Essa citação um pouco exagerada e emblemática de Pierre Nora, do início dos anos 1970, tanto indicava a tendência da mídia de abordar o passado, matéria-prima da História e da memória, como fomentava o que o historiador desenvolveu anos mais tarde sobre um filme constituir-se como um lugar de memória - para ficar apenas neste componente da mídia (NORA, 1981).

\footnotetext{
${ }^{1}$ Les mass media ont désormais le monopole de l'histoire. Dans nos sociétés contemporaines, c'est par eux et par eux seuls que l'événement nous frappe, et ne peut pas nous éviter. (NORA, 1972, p. 162).
} 
Em anos recentes, no Brasil, João Batista de Andrade, no primeiro plano de seu filme, Vlado - 30 anos depois (2005), entra em quadro, carregando uma "cadeira de diretor" dobrada, na praça da Sé, em São Paulo - espaço de diferentes tipos de transeuntes e de históricas manifestações políticas de massa -, tendo ao fundo a Catedral. Para, abre a cadeira, ainda em pé, olha para a câmera e diz:

Este é um filme que eu deveria ter feito há muito tempo. Um filme sobre o jornalista Vladmir Herzog, assassinado em uma prisão militar, há 30 anos atrás, no inesquecível 25 de outubro de 1975. [...] sua morte me chocou profundamente. Eu que sempre filmava tudo, chocado, abatido com a morte do amigo, não filmei nada. Fiquei sempre com essa sensação de que havia uma falha na minha própria carreira, na minha filmografia. [...] este filme eu dedico à memória de meu amigo e onde eu vou falar daqueles anos de chumbo.

Esse cineasta brasileiro iniciou sua carreira ainda durante a ditadura civil-militar (1964-1985), realizando filmes, constituindo memórias. Ocupa o espaço público, ao realizar filmes, conceder entrevistas e figurar em matérias de periódicos impressos, TVs e blogs, além de publicar livro autobiográfico enfatizando sua própria trajetória profissional naqueles anos de repressão. Em sua cinematografia, há filmes sobre temas do presente, encenando fatos reais do período de transição democrática (1974-1989), extraídos de crônicas policiais de periódicos de grande circulação no país. Neste texto, a atenção recai, especificamente, sobre seu filme A próxima vítima (1982/1983), que suporta certa memória do período em questão. ${ }^{2}$

Antes de abordá-lo, contudo, faz-se necessário retomar o apontamento de Nora para assinalar que, ao longo de décadas, desenvolveu-se certa tendência de a mídia usar o passado como ambientação de seus produtos, em diferentes países. Produziram-se

\footnotetext{
${ }^{2}$ Como toda periodização é arbitrária e controversa, recortamos temporalmente o período de transição no Brasil entre 1974 e 1989, sendo que o primeiro marco temporal consiste no início do governo militar de Geisel, quando se acenou com a distensão política, também denominada abertura política - lenta, segura e gradual. Já o segundo marco, refere-se à primeira eleição direta para presidente da República, após o golpe civil-militar de 1964. Todavia, o ano de 1979, com o acordo de anistia política e a revogação dos Atos Institucionais, caracteriza com maior precisão o início da transição. Além disso, já em 1985, apesar de a eleição ter sido restrita ao Colégio Eleitoral de deputados, o primeiro presidente civil da República foi eleito, após o referido golpe - o que leva alguns estudos a tomarem essa data como fim do regime ditatorial e como marco temporal da transição. Do mesmo modo, como não se efetivou "a justiça de transição do período em questão", não revisando o passado de violência política perpetrada pelo Estado, com a conivência da sociedade, é possível considerar que a transição no Brasil configura um período ainda inconcluso.
} 

pelo passado", de dimensão transnacional ou global (HUYSSEN, 2014; ROUSSO, 2007).

Embora, desde o fim da Segunda Guerra mundial, se localizem narrativas e testemunhos sobre contextos de batalhas e de campos de concentração nazistas (posteriormente também de campos soviéticos), esse olhar para acontecimentos de outras épocas adquiriu contornos renovados já no final da década de 1960, "no rastro da descolonização e dos novos movimentos sociais em sua busca por histórias alternativas e revisionistas" (HUYSSEN, 2000, p. 10; ROUSSO, 2016 a) - é o momento em que se iniciam as investigações sobre os excluídos ou os vencidos na História.

Tal movimento acentuou-se ainda com a queda do muro de Berlim, mais especificamente com o declínio do comunismo e o fim da guerra fria, alcançando a Europa Central e Oriental e reverberando em países que passaram por ditaduras na América Latina e pelo apartheid como a África do Sul (ROUSSO, 2007, p. 9, tradução nossa). ${ }^{3}$

Em países que vivenciaram ditaduras, esse olhar sobre o passado implicou questionamentos sobre a violência perpetrada em tal período, bem como suscitou a indagação sobre o significado da adesão de parte da população aos governos que se valeram de tal recurso. De acordo com Marc Ferro: "as violências, que nem sempre são simbólicas, nascidas dessas experiências históricas, estão longe de serem fortuitas, enraizando-se nas disputas históricas que as produziram" (FERRO, 2008, p. 10, tradução nossa). ${ }^{4}$

Henry Rousso, por sua vez, acrescenta que a memória é uma "experiência da perda". "Ela é uma presença do passado que nós revemos parcialmente pelas lembranças, mas ela é também a consciência da ausência, de tempos que passaram e de

\footnotetext{
3 “[...] elles ont sans doute précipité la disparition durable d'autres systèmes dictatoriaux en Amérique latine, ou de l'apartheid en Afrique du Sud, entraînant de nombreux pays à s'interroger sur la gestion immédiate ou à moyen terme de leur passé à une échelle inusitée depuis 1945" (ROUSSO, 2007, p. 9).

${ }^{4}$ Les violences, qui ne sont pas toujours symboliques, nées de ces expériences historiques sont loin d'être fortuites; elles s'enracinent dans le contentieux historique qui les a sécrétées. (FERRO, 2008, p. 10)
} 
tempos que se alteram" (ROUSSO, 2016a, p. 32, tradução nossa). ${ }^{5}$ Voltar-se, portanto, para o fecundo passado é fomentar tensões de memórias diversas, o que promove, diretamente, dois níveis de discussão, caros aos estudos desse campo: a relação entre História e memória; os conflitos de memórias, denominados na literatura europeia como “guerras de memórias” (BLANCHARD, 2008a) e, no Brasil, “embates de memórias” (REIS, 2014; FICO, 2004).

A despeito de tais debates escaparem ao propósito deste texto, vale destacar que para demarcar a diferença entre História e memória, de maneira bastante sucinta, Rousso assinalou que

a memória implica diretamente o "eu" do sujeito: sua razão, sua reflexão, sua sensibilidade, sua preocupação, sua relação com algo que está no passado e que, em geral, lhe concerne. Já a história introduz uma narrativa, uma construção, uma tomada de distância (FILMER LE PASSÉ, 2003, p. 29, tradução nossa). ${ }^{6}$

O historiador acrescenta que a abordagem do passado em determinados objetos culturais permite caracterizá-los como memória, o que corresponde à perspectiva de Michel Pollack, segundo a qual um filme configura um suporte de memória, inserindo-se nas disputas e ampliando o debate. De acordo com suas palavras,

Nas lembranças mais próximas, aquelas de que guardamos recordações pessoais, os pontos de referência geralmente são de ordem sensorial: 0 barulho, os cheiros, as cores... Ainda que seja tecnicamente difícil ou impossível captar todas essas lembranças em objetos de memória confeccionados hoje, o filme é o melhor suporte para fazê-lo: donde seu papel crescente na formação e reorganização, e, portanto, no enquadramento da memória. Ele se dirige não apenas às capacidades cognitivas, mas capta as emoções [...]. O filme-testemunho e documentário tornou-se um instrumento poderoso para os rearranjos sucessivos da memória coletiva e, através da televisão, da memória nacional (POLLACK, 1989, p. 12).

\footnotetext{
${ }^{5}$ La mémoire, sociale ou psychique, est d'abord une expérience de la perte. Elle est certes une présence du passé que l'on revit en partie par les souvernirs, mais elle est aussi une conscience de l'absence, du temps révolu, du temps qui altère (ROUSSO, 2016a, p, 32).

${ }^{6}$ Dans le Je me souviens, d'abord il y a un Je: un sujet qui se souvient. L'opération fondamentale qu'il fait, c'est de parler au présent. II dit: Voilà quel est, pour x raisons, l'état actuel de ma réflexion, de ma sensibilité, de mes préoccupations, par rapport à quelque chose qui est passé, qui en général me concerne. Ceci pose la question des rapports entre l'individuel et le collectif. En revanche, dans Il était une fois, on introduit un récit, ce qui veut dire: une construction, une argumentation, une prise de distance (FILMER LE PASSÉ, 2003, p. 29).
} 
Essa relação entre filme e memória vai ao encontro das observações de DidiHuberman sobre a possibilidade de sobrevivência das imagens, em relação à efemeridade humana, o que acaba por imputar às imagens elementos de futuro, a ponto de elas “terem mais memória e mais porvir do que o ente que a olha” (DIDI-HUBERMAN, 2013.).

Ao radicalizarem essa perspectiva, certos estudos são categóricos em afirmar que não há memória sem suportes técnicos e que dificilmente o passado sobreviveria sem a materialidade inscrita em certas culturas e tradições. A memória não prescinde, portanto, de artifícios de linguagem (FERREIRA; AMARAL, 2004, p. 137).

Nessa perspectiva, Almeida acentua que o cinema "é uma invenção moderna, no sentido material-técnico, porém a forma como suas imagens são produzidas é homóloga à produção da memória artificial” (ALMEIDA, 1999, p. 56). Para ele, o cinema simultaneamente cria ficção e realidades históricas como produz memória, sendo que o espectador, ao assistir a um filme, envolve-se também em um processo de recriação da memória (ALMEIDA, 1999, p. 56).

Trata-se, pois, de considerar o caráter seletivo e de produção de imagens idealizadas, intrínseco à ideia de memórias fabricadas, apontada por Blanchard e VeyratMasson no seguinte trecho:

Pode-se aceitar a ideia de que não há memória espontânea (Pierre Nora), há sim memórias "fabricadas" no sentido comunicante da palavra. A memória responde a certas necessidades, mas ela se inscreve também em um processo de produção que funciona segundo uma relação de força evidente (BLANCHARD; VEYRAT-MASSON, 2008a, p. 45, tradução nossa). ${ }^{7}$

Esse aspecto artificioso da memória, tão presente em objetos culturais, já observado por Milton Almeida, como memória artificial, que resulta "da arte do método" (1999: 67), remete a outro nível de abordagem: o conflito de memórias ou "guerras de memória", no qual um filme, para ficar neste componente midiático, desempenha papel relevante.

\footnotetext{
7 On peut accepter l'idée qu'il n'y a pas de mémoire spontanée (Pierre Nora) mais bien des mémoires " fabriquées » au sens communiquant du mot. La mémoire répond certes à un besoin, mais elle s'inscrit aussi dans un processus de production qui fonctionne selon un rapport de force évidente (BLANCHARD; VEYRATMASSON, 2008a, p. 45).
} 
De maneira bastante geral, já que não é um ponto de atenção deste artigo, podese assinalar que tal embate implica disputas de interpretação ou versões distintas sobre acontecimentos passados, que se circunscrevem em âmbito nacional, podendo ter "uma realidade transnacional” (BLANCHARD; VEYRAT-MASSON, 2008b, p. 16, tradução nossa). ${ }^{8}$

A disputa de memórias, especialmente em países europeus, gira em torno de temas como "escravidão, nazismo, colonização, fins de ditaduras..." (BLANCHARD; VEYRAT-MASSON, 2008b, p 15, tradução nossa). Já no Brasil, esse debate guarda a proeminência de estudos sobre o período da ditadura civil-militar (1964-1985).

Desde a última abertura política - "lenta, segura e gradual” - no Brasil, em meados dos anos 1970, localiza-se um movimento típico de transições para democracias, no qual se procurou revisar o passado de ditadura, por meio da profusão de publicações de relatos, testemunhos, memórias, que construíam certas visões sobre o período de governos militares no país. Sobre esse aspecto, Carlos Fico assinalou que

as primeiras revelações mais precisas, descrevendo os subterrâneos do regime, provieram das memórias. Há a memória da esquerda, de grande impacto editorial, sobretudo a dos militantes que experimentaram os desacertos da "luta armada" e, derrotados, compuseram pungente narrativa sobre a tortura. Como em contraposição, a memória dos próprios militares, alguns desgostosos por terem sido afastados do poder, outros tentando defender supostas positividades do regime ou pretensas necessidades inexoráveis de repressão (FICO, 2002, p. 251).

Os estudos sobre essa produção de memórias, relativa ao último período de ditadura no Brasil, têm esquadrinhado certa versão segundo a qual a memória dos vencidos teria se sobreposto à dos vencedores, a despeito de os militares terem esfacelado as organizações de esquerdas revolucionárias e governado o país durante 21 anos. Em tais trabalhos, investigam-se, entre outros aspectos, as condições de estabelecimento da situação peculiar em que “o vencido tornou-se o ‘dono' da história” (ROLLEMBERG, 2006, p.81).

\footnotetext{
${ }^{8}$ Ces « guerres de mémoires » sont évidemment composées de combats particuliers [...] traitent souvent de " ces grandes batailles " de la mémoire qui ont marqué les consciences. Ces batailles sont souvent inscrites, comme l'histoire elle-même, dans le cadre national. Mais elles peuvent aussi avoir une réalité transnationale [...] (BLANCHARD; VEYRAT-MASSON, 2008b, p. 16).
} 
Denise Rollemberg, na esteira dos apontamentos de Reis Filho sobre o livro O que é isso Companheiro?, de Fernando Gabeira, assinala que

entre os vencidos que venceram a memória houve uma pluralidade de memórias esquecidas, publicadas sim, mas não conhecidas ou não incorporadas na memória coletiva ou incorporadas como esquecimento (ROLLEMBERG, 2006, p. 84).

A historiadora acrescenta que a memória prevalecente do período, e em especial a de Gabeira, desvela a curiosa contradição de se tratar do relato de um personagem secundário na trama dos acontecimentos, daqueles duros anos de repressão e de resistências. O êxito dessa memória reside no engendramento de um tom conciliador tanto em relação aos militares quanto em relação à sociedade. Afinal, no contexto de publicação do livro, de acordo com a referida autora, "parecia bem mais pertinente uma recuperação do passado recente que não colocasse o dedo na ferida, não abordasse as relações de identidade ou apoio ou omissão ou colaboração de parte expressiva da sociedade com o regime" (ROLLEMBERG, 2006, p. 85).

Outro aspecto da memória prevalecente do período em questão, que tem sido alvo de reexame historiográfico, refere-se ao "caráter mistificador" ou heroico das esquerdas, mais especificamente relativas à luta armada. Trata-se de revisar a caracterização das esquerdas revolucionárias, que se lançaram à luta armada, como inseridas na resistência democrática (RIDENTI, 2004). De acordo com Marcelo Ridenti,

O aspecto mistificador consiste na omissão de que as esquerdas armadas nunca propuseram um mero retorno à democracia nos moldes do pré1964, tampouco algo que prefigurasse a institucionalidade que viria a se constituir depois do final da ditadura (RIDENTI, 2004, p. 143/144).

Para o autor, na mesma perspectiva de Daniel Reis Filho e Denise Rollemberg, é anacrônico analisar os anos 1960 ressaltando a ideia de democracia, pois essa não estava posta antes de meados dos anos 1970, sendo que o tema que mobilizava era a 'revolução brasileira', “hoje tão esquecida, mas que na época tinha tal legitimidade que os golpistas logo apelidaram seu movimento de "revolução de 1964" (RIDENTI, 2004, p. 147). 
Ridenti acrescenta que a referência à democracia consistia em uma maneira de legitimar o passado de ex-guerrilheiros, que, no período de transição, passaram a constituir a oposição política e a se inserir nas instâncias do Estado, e conclui: "se as esquerdas não eram democráticas nos anos 1960, tampouco o eram as direitas e muito menos os centros" (RIDENTI, 2004, p. 147).

Daniel Aarão Reis Filho, por sua vez, mirando talvez especificamente o âmbito da política de alcance mais abrangente, no período de transição no Brasil, destaca o traço apaziguador da produção de memórias relativa à ditadura. De acordo com suas palavras,

em vez de abrir amplo debate sobre as bases sociais da ditadura, escolheu-se um outro caminho, mais tranquilo e seguro, avaliado politicamente mais eficaz, o de valorizar versões memoriais apaziguadoras onde todos possam encontrar um lugar (REIS, 2014, p. 8).

Ao considerar que a mídia entra nessa disputa, às vezes de maneira bastante incisiva, sustenta-se, também neste texto, que diferentes filmes da transição democrática brasileira (1974-1989) inserem-se na perspectiva de revisão do passado de ditadura civilmilitar - marcado pela violência perpetrada pelo Estado -, estabelecendo uma visão menos conciliadora, desvelando, isto sim, o autoritarismo e a violência política do período (CAVALCANTE, 2014).

É inegável, pois, a relevância de filmes como veículos de constituição de memórias, produzindo, difundindo discursos sobre o passado e entrando nos embates desse campo (ROUSSO, 2016b; FERRO, 2004). De acordo com as palavras de Henry Rousso, "sente-se, claramente, hoje, que, para o senso comum, um filme, uma obra de história, um programa de televisão ou um artigo de jornal podem ter o mesmo escopo pedagógico e que eles podem falar com uma capacidade equivalente sobre o passado" (Apud FILMER LE PASSÉ, 2003, p. 18, tradução nossa). ${ }^{9}$

Blanchard e Veyrat-Masson sublinham o papel das mídias nas disputas de memórias, destacando que elas constituem um certo "arsenal disponível para os

\footnotetext{
${ }^{9}$ On sent très nettement aujourd'hui que, pour le sens commun, un film, un ouvrage d'histoire, une émission de télévision ou un article de journal peuvent avoir la même portée pédagogique, et qu'ils peuvent parler avec une capacité équivalente du passé (Apud FILMER LE PASSÉ, 2008, p. 18).
} 
guerreiros da memória" e que, além de sua importância comunicacional, elas configuram suportes, veículos de memórias que podem interagir sobre o desdobramento dos conflitos em tal campo (BLANCHARD; VEYRAT-MASSON, 2008b, p.14). ${ }^{10}$

É nessa perspectiva, que se toma, neste artigo, o filme de João Batista de Andrade, tendo no horizonte as constatações de Didi-Huberman, segundo as quais,

Diante da imagem, estamos sempre diante do tempo. Como o pobre iletrado da narrativa de Kafka, estamos diante da imagem como diante da Lei: como diante do vão de uma porta aberta. Ela não nos esconde nada, bastaria entrar nela, sua luz quase nos cega, ela nos impõe respeito. Sua própria abertura - não falo do guardião - nos faz parar: olhá-la é desejar, é estar à espera, é estar diante do tempo. Mas de que gênero de tempo? Que plasticidades e que fraturas, que ritmos e que choques do tempo podem estar em questão nesta abertura da imagem? (DIDI-HUBERMAN, 2013).

Que memória A Próxima Vítima encena e a maneira como o faz é o que se passa a esquadrinhar.

\section{As lentes de João Batista de Andrade}

A filmografia de João Batista de Andrade reúne mais de uma dezena de longasmetragens e mais de 49 curtas e médias-metragens, entre documentários e ficção. Tratase de um cineasta de carreira sólida, ininterrupta, que, desde os anos 1960, realizou seus filmes trazendo sempre uma marca político-social. ${ }^{11}$

A fortuna crítica da obra de Andrade é igualmente profícua. Sua trajetória de vida e obra foi estabelecida no formato de um longo depoimento, que resultou em um perfil do cineasta, organizado por Maria do Rosário Caetano (2004). Em outro livro, O povo fala:

\footnotetext{
${ }^{10}$ Les véhicules de communication au sens large, médias, monuments, musées, chansons, films, noms de rues, lois, sont ici envisagés comme un « arsenal » à la disposition des " guerriers » de la mémoire. L'intérêt de lier cette question des mémoires à leur médiatisation consiste, non seulement à mettre en évidence l'importance de l'enjeu communicationnel mais également de montrer en quoi les supports, les véhicules de la mémoire pouvaient interagir sur l'évolution même des conflits mémoriels et ce dans une dimension " mondialisée ». (BLANCHARD; VEYRAT-MASSON, 2008b, p.14).

11 João Batista de Andrade nasceu em 1939, em Ituiutaba (MG), tendo migrado para São Paulo aos 18 anos para ingressar no curso de engenharia, na Escola Politécnica da USP. Desde a chegada à capital paulista, inseriu-se no movimento estudantil, tornando-se militante do Partido Comunista Brasileiro (PCB). Além de cineasta, ele assumiu a direção em diferentes instituições de cultura no Brasil, ao longo dos anos, inclusive, mais recentemente, tornou-se diretor do Memorial da América Latina, instalado em São Paulo.
} 
relato do contexto de ditadura, distensão e redemocratização, no qual seus filmes foram realizados. Tal obra constitui um trabalho de memória, conforme as palavras do cineasta: "a intenção desse livro é organizar ideias, calcadas basicamente na memória, no sentido de recuperar o clima de dificuldades em que se desenvolve minha própria experiência (...)" (ANDRADE, 2002, p. 29).

Se o aspecto político da filmografia de Andrade constitui uma marca do cineasta, outros elementos relativos à estética, aos temas recorrentes em sua obra e ao seu modus operandi cinematográfico, isto é, à sua "maneira de filmar", sobressaem em diferentes filmes. Sua incursão pela televisão nos anos 1970, realizando reportagens com um olhar de cineasta, tornou-se determinante para fortalecer tais traços.

O ingresso de João Batista de Andrade na TV Cultura, em 1972, em pleno governo Médici, para realizar reportagens especiais para o telejornal Hora de Notícia, a convite de Vladimir Herzog e Fernando Jordão, que já trabalhavam na emissora, resultou do reconhecimento - e alinhamento político, de oposição ao regime militar - quanto ao caráter inovador de seu primeiro trabalho solo, o documentário, média-metragem, Liberdade de Imprensa (1966/1967). Andrade destacou que esse filme foi sua "porta de entrada" para a TV e acrescentou, ao mencionar a colaboração de João Silvério Trevisan que fez a assistência de direção e colaborou na elaboração dos "métodos de filmagem" usados em seu filme - que

Nós estávamos um pouco vacinados por um tipo de cinema carregado de entrevistas, um cinema chato, insosso, pouco convincente e ineficaz, que parecia alimentar as ideias de muitos cineastas influenciados pelo cinéma vérité. $\mathrm{Na}$ linha de um cinema mais participante e instigante, acabei entrando diretamente no filme, como um autor que não se satisfaz com o que encontra para filmar, mas provoca a realidade para filmar 0 resultado dessa intervenção (ANDRADE, 2002, pp. 53-54). ${ }^{12}$

\footnotetext{
12 "A intervenção consistiu em entregar livros para as pessoas (de rua) e filmá-las lendo sobre a questão da liberdade e da imprensa. Além disso, o cineasta filmou a entrega de um exemplar da "revista Ação Democrática - de direita, golpista, editada por Ivan Haslocher, do instituto Brasileiro de Ação Democrática (IBAD), financiado por empresários e instituições do país e do exterior - a um jornaleiro
} 
Com isso, João Batista de Andrade não apenas desvela sua intervenção de cineasta, "problematizando a posição do diretor diante da matéria a ser retratada", como irrompe com a suposição de neutralidade em documentários. E ainda: enuncia a democratização das vozes no filme, ao deslocar o microfone de autoridades da imprensa para as "pessoas comuns", como o jornaleiro (personagem do filme). Trata-se da “construção de um olhar pluralista, algo que é muito valorizado em nossos dias, particularmente depois do impacto da cinematografia de Eduardo Coutinho" (RAMOS, 2007, p. 317). É, nessa chave, que Gilberto Sobrinho assinalou que "João Batista, desde o início, inaugura uma estilística pessoal bastante singular, tratando-se de uma poética marcada pelo tom denso da autoconsciência da linguagem" (SOBRINHO, 2013, p.14).

É certo, no entanto, que desde os anos 1960, em diálogo com o neorrealismo italiano e com a nouvelle vague francesa, diferentes cineastas (homens e mulheres) passaram a inovar a linguagem do cinema brasileiro. De acordo com Ismail Xavier,

Essa nova estética favoreceu uma quebra da fronteira entre obra de ficção e o documentário, alcançando formas originais de representação da experiência social da pobreza. Cria-se uma nova relação entre a 'câmera na mão' e o mundo que se focaliza; e se traz para a tela segmentos da população em geral excluídos. (...) Este envolvimento da prática do cinema com as condições efetivas da vida dava ensejo a um novo diálogo com o "Outro de classe", viabilizado pela mobilidade das equipes de filmagem e as novas técnicas (XAVIER, 2015, p. 216).

Sem adentrar na problematização necessária sobre a maneira como essa “democratização das vozes” é realizada na filmografia de Andrade, destaca-se apenas que, segundo o próprio diretor, com Liberdade de imprensa, ele descobriu a "verdadeira face" de seu cinema. Sua maneira de filmar aprimorou-se no meio televisivo, ao trabalhar na TV Cultura (1972-1974), fazendo dezenas de "pequenos documentários" como reportagens especiais, de três a sete minutos, e nos inúmeros documentários, já como funcionário da TV Globo (1974-1978), que preparou, especialmente, para o Globo Repórter,

(personagem do filme), e ele, pego de surpresa, revela que conhecia a revista e conta como ela era distribuída e de onde vinham os exemplares que ele vendia, o que comprometia o esquema de segurança da revista [...]" (ANDRADE, 2002, p.54). 
sendo alguns deles o média-metragem Caso Norte (1977) $)^{13}$, e, outro, longa-metragem, de formato para TV, Wilsinho Galileia (1978). ${ }^{14}$

A relação entre cinema e televisão está imbricada, portanto, na "maneira de filmar" de João Batista de Andrade. De acordo com as suas palavras:

Minha maneira de filmar, o caráter de momentaneidade dos relatos e dos depoimentos, a CAM que descobria coisas, a eletricidade da montagem, tudo me fazia próximo do jornalista de TV. De minha parte, sempre quis ver mais significados no filme e sofri um pouco com a minha mirada invertida sobre ele, como se no filme eu repetisse formas da televisão, quando, na verdade, eu havia levado, do filme, essas formas para a TV (ANDRADE, 2002, p. 56).

Ao passar pelos diferentes filmes de Andrade, realizados nos anos 1970, Alcides Ramos observou a trajetória de resistência à ditadura civil-militar, apontando o engajamento estético-político do cineasta, bem como as dificuldades para lidar com a censura e com as pressões cotidianas, inclusive de ameaça contínua de demissão. Salientou que

é possível perceber, acima de tudo, a tentativa muitas vezes dolorosa de se construir um trabalho de resistência cotidiana ao arbítrio, numa conjuntura particularmente adversa. De qualquer forma, trata-se de uma experiência estético-política fundamental para a compreensão dos caminhos trilhados por aqueles que lutaram contra a censura, tendo em vista a riqueza dos documentários produzidos (RAMOS, 2007, p. 324).

\footnotetext{
${ }^{13}$ Gilberto Sobrinho assinala que "O Caso Norte é um documentário de 1977 e trata de um tema diretamente extraído do gênero policial presente no rádio e no jornal impresso. $O$ acontecimento explorado na narrativa trata de um crime ocorrido em setembro do mesmo ano. Numa briga entre nordestinos, num bar de esquina da região da Barra Funda, centro de São Paulo, um guarda de segurança, José Joaquim de Santana, de 26 anos, de Pernambuco, dispara várias vezes o seu revólver ferindo duas pessoas e mata uma terceira, José Antonio de Moura, o Pelezinho, de 24 anos, do Rio Grande do Norte. Ambos, o jovem morto e o autor dos disparos, tinham vindo tentar a vida em São Paulo. (...) Esse acontecimento violento torna-se o ponto de partida para uma análise das condições sociais que teriam levado ao trágico evento (SOBRINHO, 2013, pp. 22-23).

${ }^{14}$ Andrea França com o propósito de analisar métodos de reconstituição de documentários brasileiros, na relação entre imagem, história e memória, selecionou filmes que reconstituem lugares de crimes, "cenas que revisitam momentos violentos e insolúveis daquilo que se passou e a relação que se estabelece entre imagens do passado e do presente". Um desses filmes é o documentário para televisão, Wilsinho Galileia (1978), de Joao Batista de Andrade. Segundo França, o filme foi "proibido pela censura federal e jamais exibido nas telas brasileiras, relata e refaz a vida do bandido Wilsinho, famoso nos anos 1970 por seus crimes, assaltos, assassinatos e prisões, morto pela polícia assim que completou a maioridade" (FRANÇA, 2010, p. 150).
} 
Acrescente-se que, para Ramos, a cinematografia de Andrade caracteriza-se pelo “diálogo permanente entre o esforço documental e a liberdade de criação ficcional, isto é, um entrecruzamento de modalidades discursivas, que promove o encontro entre documentário e ficção, sempre com base em uma perspectiva de militância política" (RAMOS, 2007, p. 315).

A experiência na televisão deu vasão também ao interesse do cineasta por determinados fatos que expuseram aspectos do regime político em curso. Tais fatos constituíram matéria tanto para suas reportagens-documentários quanto para alguns de seus filmes. As análises sobre esses filmes nos permitem perceber a circulação de certos elementos na cinematografia de Andrade, conforme observaremos a partir de seu longametragem, de ficção, A Próxima Vítima (1982/1983).

\section{A Próxima Vítima: memória de uma transição inconclusa}

Incialmente, João Batista de Andrade pretendia filmar Os Demônios, projeto inspirado na obra de Dostoievski, “mas com uma história bem brasileira”. Ambientado entre 1979 e 1981, período da anistia, seria o primeiro filme de ficção a abordar "o drama dos ex-exilados que, de volta ao Brasil, encontram um país profundamente modificado e um processo de abertura política de difícil participação" (CAETANO, 2004, p. 305). Todavia, com a censura do projeto, Andrade resolveu filmar, então, A Próxima Vítima (1982).

Tratava-se da conjuntura do início dos anos 1980, em que as proposições revolucionárias não apareciam mais como uma possibilidade viável, a curto ou médio prazos, e parte das articulações coletivas eram estabelecidas em torno da "frente de resistência democrática". Contudo, havia efervescência política no cotidiano de diferentes cidades brasileiras, onde movimentos sociais e populares assumiam a dianteira da redemocratização, como o movimento de mulheres, de negros, de estudantes, movimento contra a carestia, clubes de mães, pastorais operárias - para citar apenas alguns, além do movimento sindical. 
Batista produziu A Próxima Vítima dois anos depois de lançar o seu premiado filme O homem que virou suco (1980). ${ }^{15}$ De acordo com a sinopse desse recente projeto, o filme é uma história de sucessivos crimes ocorridos misteriosamente no Brás, bairro próximo ao centro da capital paulista, onde havia nos anos de 1970/1980 grandes indústrias e lojas populares e um amálgama de costumes e tradições dos imigrantes italianos, os primeiros a se radicarem no bairro, e de migrantes nordestinos, além de "todo um submundo que gravita em torno de pequenos hotéis, hospedarias, pensões e cortiços" (Projeto do filme/ pasta João Batista de Andrade/CEDOC). Prostitutas foram ali assassinadas a golpes de faca e de navalhas, sendo que o assassino com o sangue delas escrevia na parede o nome da futura vítima. Em meio à propaganda, comícios e agitações do clima pré-eleitoral de 1982, o repórter Davi (Antônio Fagundes) é designado para cobrir a notícia dos assassinatos. O protagonista envolve-se pessoalmente na trama, ao se relacionar com a prostituta Luna (Mayara Magri). Outros personagens compõem a narrativa: Guido (Gianfrancesco Guarnieri) é filho de italianos e vive de "pequenos biscates" pela "boca"; “Nego" (Aldo Bueno) é apontado pela polícia como o assassino; o dr. Orlando (Oton Bastos) é o delegado de polícia, responsável pelo caso. O filme desenvolve outros quadros paralelos centrados em Davi: seus problemas afetivos com a ex-esposa, com a atual namorada e com Luna, seu aparente desencanto com a atividade política, as cobranças de participação feitas por seus colegas de trabalho, o desencontrado desempenho da polícia e a busca incessante pelo assassino de Luna (idem). ${ }^{16}$

Certos elementos presentes em A próxima vítima perpassam parte da cinematografia de Andrade, conforme assinalado acima: o enfoque de "sujeitos comuns"

\footnotetext{
${ }^{15}$ Neste filme, projetam-se temas recorrentes da obra de Andrade: migração nordestina, preconceito, crimes e arbitrariedade da polícia. Frederico Castro Neves apresenta a seguinte sinopse desse longametragem, de ficção, de João Batista de Andrade: "O filme narra a história de um poeta popular, Deraldo, um paraibano que é confundido com um operário, Severino, um cearense que esfaqueia seu patrão durante a entrega do prêmio de "operário-símbolo" de sua empresa. Deraldo passa a circular pelas mais variadas formas de ganhar a vida em São Paulo, deparando-se com o preconceito e com a perseguição policial. Ao final, resolve refazer a história do seu sósia, Severino, um trabalhador que enlouquece após denunciar seus colegas e ser traído pelo patrão. $O$ resultado é mais um folheto de cordel, intitulado O homem que virou suco" (NEVES, 2001, p. 89).

${ }^{16}$ O filme antes de ser lançado, em 1983, sofreu uma retaliação cruel da censura, que impôs nove cortes que desfigurariam a narrativa. Depois de tramitar por diferentes órgãos foi parar no "Conselho Nacional de Censura, uma espécie de instância transitória criada ainda no regime militar para resolver os problemas graves de censura, já no processo de abertura política controlada". O filme acabou sendo lançado sem cortes (CAETANO, 2004, pp. 318-319).
} 
do cotidiano de cidades brasileiras, a problematização da pobreza, destacando o racismo e a prostituição, a presença do audiovisual na trama (isto é: a presença de reportagens e de mídias no próprio enredo do filme), crimes e a arbitrariedade da polícia.

Neste filme, o cineasta voltou-se para um fato das crônicas policiais tal qual fez em seu longa-metragem Doramundo (1977) - inspirado no livro de Geraldo Ferraz, que resultou em uma longa reportagem - e no Wilsinho Galileia (1978), também resultante do trabalho de repórter de João Batista. ${ }^{17}$

Para contar a história do assassinato em série de prostitutas no Brás, o cineasta encenou o cotidiano de "pessoas comuns", atribuindo vozes a sujeitos considerados marginais, como prostitutas, afrodescendentes, moradores de favelas, além de personagens que expressavam certo segmento da classe média, como os vinculados à imprensa e outros da polícia. Tais elementos encontram-se, como não poderia deixar de ser, entrelaçados na trama.

A tendência de Andrade de se ater a fatos do cotidiano - um traço forte da investigação jornalística - remete à reconfiguração do sentido mesmo de acontecimentos, já observado por Nora, no início dos anos 1970, ao se apoiar no texto de Barthes sobre Fait divers (1964). ${ }^{18}$ Para Nora, o acontecimento deixou de ser um monopólio do historiador. Ele parte do externo, "com todo o peso de um dado, antes da sua elaboração, antes do trabalho do tempo". Ele adquire "tanto mais força quanto as mídias impõem imediatamente o vivido como história e quanto o presente nos impõe mais do vivido" (apud Rousso, 2016b, p. 202).

Na primeira sequência do filme, o repórter Davi, deitado em sua cama, ouve um locutor no rádio noticiar: "a ordem é garantir a tranquilidade nas eleições. Bombas de gás lacrimogêneo explodiram no meio de cinco mil pessoas que se preparavam para assistir

\footnotetext{
${ }^{17}$ De acordo com Alcides Ramos, o filme Doramundo (1977) "apresenta-se como uma obra alegórica que coloca em tela as condições de vida e o cotidiano durante o período da ditadura militar brasileira. Para tanto, utiliza como ponto de partida uma narrativa que mostra a mudança provocada na rotina e no comportamento dos habitantes de uma pequena cidade ferroviária do interior de São Paulo por uma sucessão de mortes estranhas" (RAMOS, 2007, pp. 325-26).

18“"A expressão fait divers não tem correspondente exato em português. Designa a 'rubrica sob a qual os jornais publicam os acidentes, os pequenos escândalos etc.' (Petit Larousse). (N. da T.)" (BARTHES, 1964). Nora, a partir deste ensaio de Barthes, discorre sobre as implicações e diferenças entre fato e acontecimento, tanto para a mídia quanto para a História (NORA, 1972).
} 
Em outra sequência, após uma relação sexual frustrada com Teresa (Louise (ardoso), sua colega de trabalho, o repórter levanta-se nu, liga a televisão e vê um programa no qual ele aparece entrevistando um homem que está vendendo o próprio rim; em seguida, entrevista outro homem, idoso, nordestino, enfermo em uma cama de hospital, que diz precisar de um rim novo para viver e que não tem dinheiro para comprálo. Consternado com esse "mundo cão", o repórter muda o canal de TV, e se depara com a sintonização de uma propaganda de Jânio Quadros para governador.

Note-se que a renúncia desse político à Presidência da República, em 1962, está diretamente relacionada ao golpe civil-militar de 1964. Desse modo, infere-se que a referida sintonização de sua candidatura, no filme, não é gratuita, mas sim um chamamento à lembrança sobre um período no qual se acentuaram a desigualdade social e a repressão, e mais: aquele "mundo cão" era um de seus desdobramentos.

Em outro momento do filme, Davi Duarte caminha por uma praça da cidade, em clima de campanha eleitoral, sendo abordado por pessoas que distribuem panfletos e argumentam, ao seu lado direito, em prol de Montoro, e, outras, ao seu lado esquerdo, em prol de Lula - ambos eram candidatos ao governo de São Paulo, em 1982 - sendo que em outra cena enquadra-se também a campanha de Reinaldo de Barros. Ao chegar ao escritório da TV, atribuem ao repórter o caso de assassinatos no Brás.

A trama consiste na história de uma reportagem sobre tal fato, o que é um recurso que poderíamos denominar de “meta-mídia”, isto é, a presença do audiovisual no próprio filme, mostrando espaços jornalísticos da televisão ou de produção da notícia, programas de TV, jornais impressos. Nesse movimento, a câmera percorre ruas, o local do crime, instâncias do Estado, moradias dos envolvidos. O cineasta constrói sequências da trajetória do repórter na elaboração da matéria.

Davi desloca-se para o hotel em que prostitutas foram assassinadas, em companhia de um cameraman para apurar o fato. No percurso, no carro de reportagem, 

enquadrados na cena.

Em outra sequência, à noite, o repórter volta ao Brás, fazendo tomadas de rua, onde lança luz sun-guns de bateria em prostitutas que se encontravam na calçada, assustando-as como se fosse uma batida policial. Ele avista a jovem prostituta Luna e a persegue até o hotel. Na cena, em uma escada no interior da hospedaria, insistindo para que ela converse com ele, pede ao porteiro que diga a ela que ele não é policial. 0 porteiro o reconhece e diz para a garota que "ele é da televisão"; passa por eles um homem negro, acompanhado de uma mulher, e ambos descem a escada. Davi pede o depoimento de Luna sobre o maníaco, já lhe fazendo algumas perguntas, mas sem gravar porque ela não aceita participar da reportagem. Há nessa associação do repórter com a polícia certa crítica de João Batista à mídia colaborativa, que continuava a receber os releases oficiais e acompanhava a polícia em suas incursões repressivas pela cidade, produzindo a notícia do ponto de vista das autoridades policiais (ANDRADE, 2002, p. 33).

Na rua, já à luz do dia, o repórter orienta seu colega a fazer tomadas das pessoas que saem da estação do Norte, no Brás. Nesta sequência, Davi encontra Guido, que diz ser "dentista, cuidar das meninas", e prolonga o contato com ele. Almoçam juntos em uma cantina italiana no Brás, bebem e, numa cena noturna, andam juntos embriagados pela rua, quando, ao urinarem em uma parede, Guido identifica um cartaz com a foto de campanha de Montoro e pede desculpas ao senador. Davi intervém: "Não se preocupe, ele está falando, não está vendo nada!”. A situação é um indício da insatisfação do protagonista com a oposição. Para Ramos, "a cena e o filme são muito elucidativos a respeito da avaliação negativa que João Batista de Andrade estava fazendo das forças políticas de oposição naquela conjuntura" (RAMOS, 2007, p. 330).

Uma das prostitutas indicadas por Guido aceitou vender o seu depoimento para Davi. No carro de reportagem, circulando pelas ruas, a prostituta e o repórter encontramse sentados no banco de trás da Caravan. Já o cameraman, alojado no maleiro, tenta enquadrar o melhor ângulo da silhueta daquela personagem. Davi pergunta se ele está 
gravando, ao que o câmera responde, pedindo para a entrevistada virar um pouco mais em sua direção. Ela recusa, destacando que o combinado era filmarem-na de costas. ${ }^{19}$ Ao confirmar que está gravando, o repórter inicia a tomada do depoimento, cujo trecho segue abaixo:

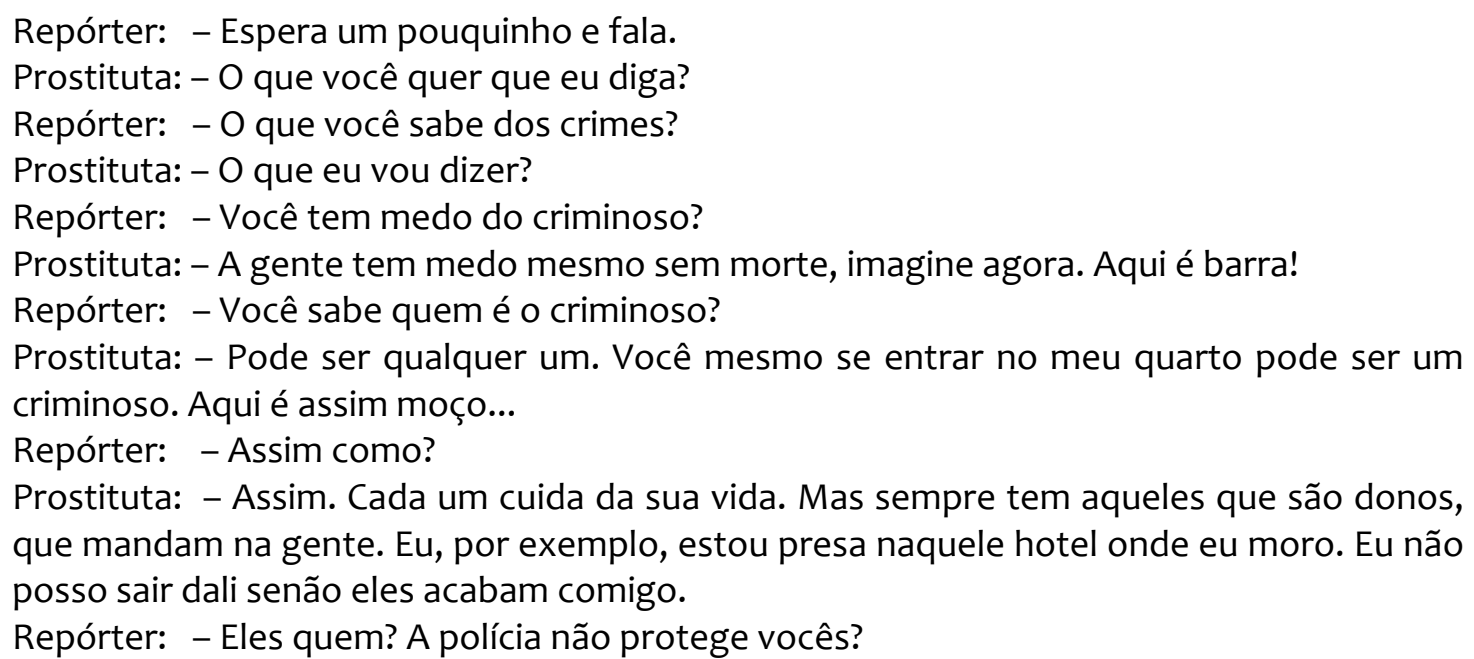

A prostituta, ao ser indagada sobre a proteção da polícia, vira o rosto e dá um sorriso constrangido, em sinal de negação. Em seguida, afirma: "a polícia protege ela mesma". ${ }^{20}$ Se esse diálogo evidencia uma das características da filmagem de João Batista de Andrade, relativa à pluralização de vozes, inclusive de sujeitos marginalizados, e da presença do audiovisual na trama, permite ainda refletir sobre o acontecimento, na perspectiva do historiador, conforme apontado por Nora. Segundo esse autor, o "acontecimento testemunha menos pelo que ele traduz do que pelo que ele revela, menos do que ele é do que pelo que ele provoca" (apud Rousso, 2016b, p. 203). ${ }^{21}$

\footnotetext{
${ }^{19}$ É uma cena tensa, em que o repórter parece irritado com a prostituta, alterando o tom de voz, em certos momentos do depoimento. Também pode revelar certo desrespeito e até machismo do protagonista em relação a essas mulheres prostitutas. Saliente-se que, em uma discussão entre Davi e o chefe da redação, a conversa descambou para o fato de ele ter tido relações sexuais com a Luna, a jovem prostituta. Teresa, que ouvia tudo, saiu da sala dizendo que o assunto havia declinado para o machismo de sempre deles.

${ }^{20} \mathrm{O}$ caso verídico de assassinato em série de prostitutas do Brás configura matéria de diferentes artigos publicados na Folha de São Paulo, em maio de 1982 - levantado por Vaneildes Faria, pesquisadora PIBIC, na Faculdade de História, da UFG.

${ }^{21}$ Acrescente-se que Ramos observa o uso desse recurso também no filme $O$ homem que virou suco e destaca: "Outro momento significativo dessa fusão entre ficção e documentário refere-se ao audiovisual que faz parte do filme e que é apresentado aos migrantes nordestinos que trabalham nas obras do
} 
Nesse sentido, os assassinatos no Brás e o depoimento da referida personagem tornam-se emblemáticos da situação de insegurança que as prostitutas viviam em São Paulo, no início dos anos 1980. Reiteram os apontamentos de Margareth Rago quanto ao fato de as mulheres em tal situação viverem sem qualquer respaldo social, desprotegidas, vulneráveis às múltiplas formas de assédio moral e sexual e de violência física, sendo privadas de seus direitos civis e "responsabilizadas pela existência da prostituição" (RAGO, 2011, p. 212). Abrem possibilidades para se verificarem as relações de gênero, especialmente o machismo e a violência contra as mulheres, fomentados no regime autoritário e que persistiam naqueles anos de redemocratização, por ocasião das reclamações dos movimentos de mulheres e feministas.

Note-se que o próprio filme de Batista mostra o machismo do protagonista, que, em uma cena, reclama da ex-esposa porque ela estava acompanhada de um homem em sua casa, como se ela não pudesse refazer sua vida amorosa após a separação. Além disso, Davi apresenta certo perfil socialmente aceito quanto ao comportamento masculino: ter uma ex-esposa, uma amante no trabalho e estabelecer relações sexuais com uma prostituta - a mais jovem e considerada a "bonitinha da zona".

A situação de vulnerabilidade daquelas mulheres, em situação de prostituição, agravava-se com as repressivas Operações Limpeza. Tais ações policiais eram conduzidas pelo delegado Richetti, que visava a impedir a circulação de prostitutas, travestis e homossexuais nas ruas da cidade. ${ }^{22}$ Tanto é assim que, à Folha de São Paulo, o referido delegado declarou: "Nós vamos continuar botando para quebrar, 24 horas por dia, até limpar a área". Na matéria consta que

metrô paulista. Seu conteúdo, claramente, tem como objetivo contribuir para a quebra da cultura desses migrantes, ridicularizando seus hábitos e costumes. Ocorre, porém, que o audiovisual presente no filme é uma recriação do próprio diretor, tendo em vista das dificuldades em obter a obra original. João Batista teve contato com essa peça de treinamento quando fazia uma reportagem para a Rede Globo. Essa estratégia, em nossa avaliação, sintetiza o gesto criativo do diretor que procura fundir ficção e documentário" (RAMOS, 2007, p. 329).

${ }^{22} \mathrm{Em}$ outro filme de João Batista de Andrade, Doramundo (1977), prostitutas compõem a trama, ao serem levadas para a cidade ferroviária, do interior paulista, que é ambientada no filme (RAMOS, 2007, p. 326). 
Horas depois [do início da "Operação Limpeza"], um hotel estava completamente destruído, 172 pessoas haviam sido presas. [...] De sábado para domingo, porém, nova investida: "você pode escrever aí que prendemos mais de 700". Entre os presos, segundo o delegado, havia homossexuais, travestis, prostitutas e um elemento com posse ilegal de arma, "que reagiu à prisão". [...] explicou Richetti: "agora não é mais ‘Operação Limpeza'. É 'Operação Rondão”' (Folha de São Paulo, 27 de maio de 1980).

A matéria elucida ainda que outro delegado, da equipe de Richetti, havia participado da Operação Limpeza, nos anos 1960. Esse procedimento da polícia paulista revela a permanência em pleno período de transição democrática tanto do autoritarismo como do projeto moral da ditadura civil-militar brasileira - que consistia na afirmação da família nuclear heterossexual e nos papéis tradicionais de gênero, reprimindo quaisquer manifestações contrárias a esse modelo (CAVALCANTE, 2016). Em A próxima Vítima, tal operação é encenada e mostra a arbitrariedade e a truculência policiais.

Em outra cena do filme, Davi fala para Teresa sobre a sua descrença na oposição, mencionando que latifundiários e empresários nunca vão ficar ao lado do povo. Acrescenta não acreditar que a oposição possa fazer algo para resolver o "mundo cão" que ele está vivendo, não pode fazer nada sobre a miséria que ele vê todos os dias, onde “a polícia manda mais do que o governo". Note-se que essa descrença do protagonista é construída, a despeito de o cineasta, em 1982, coordenar a campanha eleitoral do PMDB, em São Paulo.

O filme, como a imagem analisada de Didi-Huberman, convida, então, o espectador ao presente da transição democrática. Nas palavras desse historiador da arte:

Diante de uma imagem, não importa quão recente, quão contemporânea ela seja -, o passado também não cessa jamais de se reconfigurar, pois esta imagem não se torna pensável senão em uma construção de memória, chegando ao ponto de uma obsessão (DID-HUBERMAN, 2013).

João Batista de Andrade destaca, inclusive no filme, que essa polícia reproduzia o estereótipo do “negro bandido' (mistura de malandro e favelado) - o que foi problematizado na trama em questão (STAM, 2008). Nego é acusado pelo delegado Orlando de ser o assassino do Brás, em rede nacional de televisão. Davi, convencido do 
contrário, certo da farsa policial, procura a namorada de Nego, Sílvia (atriz negra não identificada nos créditos do filme). No diálogo entre os dois, o repórter defende que a única coisa que pode provar a inocência de Nego é "ele ir à televisão e desmentir o Orlando". Para tanto, pede a Sílvia para mediar um encontro entre eles a fim de viabilizar a tomada do depoimento do namorado. Diz que precisa conversar com o suposto criminoso para "provar que a polícia se enganou”.

A ingenuidade do repórter, que havia recebido a foto do suposto criminoso por meio do delegado Orlando e entregue à emissora de TV, é posteriormente achincalhada pelo próprio Nego, em uma cena violenta, ambientada num bairro pobre, na qual humilha o repórter, ao urinar sobre ele. O chefe de edição, do programa de TV, também compara Davi a um estudante de 1968. Sílvia, igualmente, o desdenha, ao olhar para a câmera e dizer: "a polícia?! A polícia não se engana. Eles pegam quem quer. O Nego não topou fazer a brincadeira deles, olha aí no que deu: estão se vingando".

A ingenuidade do repórter aparece também em diferentes momentos em que ele afronta o delegado. Tanto que esse lhe adverte, como lembra o articulista Amylton Almeida: "os tempos são outros, por isso, ele não precisa mais prender artistas, intelectuais, jornalistas. Estamos numa democracia" (Gazeta de Vitória, 31 de julho de 1986).

Na sequência em que Davi se encontra com o irmão de Nego (João Acaiabe), auxiliado por Sílvia, para conduzi-lo até o suposto criminoso, eles seguem rumo à periferia, e a criminalização racial é evidenciada na fala do irmão, transcrita abaixo:

Vocês não gostam de negro. Esse é o problema! Não diga que não é. Vocês sempre dizem a mesma coisa. Mas a verdade é que você é o branco, você é o repórter. É o que aparece na televisão, é o bom. O outro é o negro, é o bandido. Faltou o bandido para mostrar, é só achar o negro. E aí fica tudo certo. Se houver outros crimes... Fácil: é só encontrar mais um negro. Nós somos muitos, somos até a maioria.

Esse tema revela a percepção que João Batista de Andrade guardava desde os anos 1970 sobre "os problemas sociais se travestirem em problemas policiais". O cineasta 
Era uma operação militar de rotina, a invasão aparatosa de uma favela, à noite, por soldados super armados, cães e cavalos, onde as pessoas eram tiradas das camas para se identificar. Eu me lembrava [...] da forma repetitiva dessas reportagens violentas: a CAM que seguia a invasão, do lado dos policiais, a luz dos sun-guns de bateria estourava feito tiros nos olhos das pessoas, as portas frágeis sendo arrombadas a pontapés [...] Eram imagens cruéis, sem críticas. Pelo contrário, ajudavam a sedimentar o preconceito e a identificar miséria com marginalidade, questão social com questão policial (ANDRADE, 2002, pp. 57-58).

A problematização desse tema no filme de Andrade, de 1982/3, em que Nego é acusado injustamente de criminoso pela polícia, configura mais um indício dessa memória sobre a arbitrariedade da polícia, que persistia no período de transição. Evidencia a permanência de aspectos autoritários do regime de ditadura civil-militar em plena transição democrática. ${ }^{23}$

É possível assinalar ainda que a crônica policial inspirou a construção do personagem Nego. Contudo, a suposição do crime é desacreditada pelo repórter, que desassocia a relação entre a questão racial, a pobreza e a criminalidade. Diferente do artigo da Folha de São Paulo sobre o assassinato de mulheres no Brás, no qual consta que:

A polícia procura o assassino ou os assassinos. Dois dos casos, segundo os policiais do Deic, já estão esclarecidos e o criminoso foi José Carlos Maximiliano Ruas, um negro alto, boa pinta, 30 anos, já envolvido em 42 processos por roubos e assaltos e dois homicídios, que frequentava muito "a boca", no Brás, namorando e explorando "as meninas" (Folha de São Paulo,16 de maio de 1982).

\footnotetext{
${ }^{23}$ Todavia, essa evidência de permanência não invalida a localização de outros elementos que desvelam a perspectiva de mudanças, engendrada pelas mobilizações e organização de sujeitos sociais, em tal período. Trata-se de uma conjuntura marcada também pela emergência de novos movimentos sociais, como, por exemplo, os de mulheres e de negros. É também marcado pelas fundações do Partido dos Trabalhadores (PT) e da Central Única dos Trabalhadores (CUT), além do expressivo movimento de massa pelas Diretas Já. E ainda: mesmo em filmes de João Batista há sinais desse "clima de novidade", de mudança que se desenhava, como, por exemplo, em Greve! (1979) - o que configura bem um período de transição em que há projetos em disputas.
} 
Acrescente-se que João Batista também já havia feito uma reportagem especial, em 1972, para a Hora da Notícia sobre uma farsa policial. Ele apurou que o radialista, da Rádio Bandeirantes, Milton Parron, resolveu entrevistar um suposto criminoso. De acordo com o cineasta:

Em poucas palavras, havia um crime e um suspeito preso. Naquele dia, todos os jornais saíram com manchetes anunciando a confissão do criminoso. A fonte: o delegado, a quem o preso teria confessado o crime. Com os jornais já nas bancas e a notícia em veiculação nas rádios e TVs, Milton Parron leva ao ar (Rádio Bandeirantes) uma longa entrevista com o próprio suposto criminoso, na qual ele nega veementemente que tivesse confessado e, na verdade, revela uma farsa montada pelo delegado (ANDRADE, 2002, p. 32).

Se Andrade tomou a crônica policial como inspiração de seu filme, também tomou sua reportagem, mencionada acima, para construir o personagem Davi e a farsa policial na qual Nego fora envolvido. Essa relação entre a violência policial e os crimes no filme, bem como entre o filme e aspectos da sociedade paulista, dos anos de 1980, são abordadas ainda por João Batista, no seguinte trecho:

A violência vivenciada pelo repórter, no filme, prenuncia uma violência inimaginada, que explodiria logo no primeiro ano do governo Montoro. Uma violência que acabou fazendo do filme, no lançamento em 83, uma espécie de reportagem do que acontecia não lá atrás, mas de agora, da época de sua exibição. A frase do filme "um assassino anda solto pelas ruas, alguém precisa impedir que haja novamente" se confundia com as sucessivas manchetes de todo tipo de violência, assassinatos, assaltos, sequestros, assassinatos de crianças (CAETANO, 2004, p. 316).

Nesse relato de João Batista fica claro o seu olhar sobre o imediato, ao tratar a ocasião de realização do filme, um ano depois do lançamento, como algo já de outra época. Faz jus ao título de seu perfil, organizado por Maria do Rosário Caetano: “um cineasta da urgência e da reflexão". Além disso, evidencia a relação que ele estabelece entre seu filme e as questões colocadas naquele período de redemocratização, especialmente relativas à violência. O cineasta afirmou ainda, em entrevista concedida ao Correio Brasiliense, por ocasião do lançamento, que seu filme "é um mergulho na marginalidade, na violência, no medo, na arbitrariedade da polícia, justamente no 
momento em que se vive a expectativa histórica de mudança pelas eleições" (Correio Brasiliense, 10 de maio de 1983).

Trata-se de um filme testemunho, que "fixa o presente". Nas palavras de Michèle Lagny:

É o primeiro objetivo do registro do presente, seja ele mais ou menos falsificado, seja tratando da informação (atualidades), de pesquisas ou de análise (sob a forma de montagens documentárias, ou até de ficções do imediato) para fixar um momento que parece importante e alimentar a imagem do presente e, depois, uma futura memória (LAGNY, 2012, p.29).

Mas esse olhar do diretor sobre o presente não agradava completamente, como não poderia ser diferente. Na Gazeta de Vitória, o articulista Amylton de Almeida considera tudo muito gratuito para o espectador "porque o diretor quer dizer verdades. Todas muito conhecidas sobre inflação, política, ditadura, etc. e tal” (Gazeta de Vitória, 31 de julho de 1986).

Maurício Lelo, de O Estado de São Paulo, afirma que o novo filme de João Batista de Andrade, A próxima Vítima, "é uma obra polêmica, mas já alcança o respeito da crítica que o aponta talvez como o melhor filme do ano" (O Estado de São Paulo, s/d). Em outra matéria, do mesmo jornal, intitulada "O cinema que discute a realidade", o articulista destaca que "há uma rigorosa aplicação técnica, mas o cineasta prefere que vejam o filme como uma reflexão sobre a realidade política e social de hoje - daí a pressa em lançá-lo porque os temas estão quentes" (O Estado de São Paulo, 13 de novembro de 1983). ${ }^{24}$

Se João Batista anunciou mesmo a urgência quanto ao lançamento do filme devido à atualidade dos temas tratados naquela conjuntura, isso demonstra sua intenção em intervir na realidade, confirmando os apontamentos de Gilberto Sobrinho a respeito de ele realizar um “cinema de intervenção" - não apenas no fazer cinematográfico, mas também no presente (SOBRINHO, 2013).

\footnotetext{
${ }^{24}$ Duas matérias de jornais sobre esse filme, meses depois do lançamento, destacam que o cineasta encontrava-se em Paris, para comercializar A próxima vítima na Europa, sendo que havia levado uma cópia para os selecionadores do Festival de Cannes inseri-lo na mostra Quinzena dos realizadores, plataforma de lançamento de filmes brasileiros na Europa (O GLOBO, 11 DE ABRIL DE 1984). No Brasil, o filme passou também por festivais como o de Gramado. Todavia, João Batista declarou que é o filme menos premiado de sua carreira (CAETANO, 2004, p. 317).
} 
Para finalizar, considera-se que o assassinato de mulheres, em situação de prostituição, no filme $A$ Próxima Vítima, consiste na encenação de um acontecimento, do início dos anos 1980, confirmado pela crônica policial daqueles anos, que coloca em cheque se a transição democrática significou continuidade ou mudança em relação à ditadura civil-militar. O diálogo deste longa-metragem, de ficção, com outros filmes e reportagens do cineasta - realizados durante a ditadura civil-militar - confere a esse artefato cultural midiático o caráter de documento, pois, testemunho de sua época, engendra certa memória de uma transição democrática, quando ainda eram muito fortes os aspectos do período anterior. Persistia a arbitrariedade e a truculência da polícia, a complacência e colaboracionismo da imprensa, os problemas sociais, a discriminação racial, a violência contra as mulheres.

A Próxima Vítima configura, assim, certa memória dos anos de sua realização e lançamento que indica a continuidade, isto é, a ausência de ruptura com o passado autoritário, mostrando a truculência policial, a conivência da mídia, o machismo e a criminalização racial. Desse modo, o filme não constitui uma memória apaziguadora conforme a tendência prevalecente naqueles tempos de redemocratização (ROLLEMBERG, 2006; REIS, 2014). O protagonista do filme só podia ficar desolado ao final da trama, com o assassinato de Luna. 


\section{Referências}

ALMEIDA, Milton José. Cinema: arte da memória. Campinas: Autores Associados, 1999.

ANDRADE, João Batista de. O povo fala: um cineasta na área de jornalismo da TV brasileira. São Paulo: Ed. SENAC, São Paulo, 2002.

BARTHES, Roland. A estrutura do Fait divers. In: BARTHES, Roland. Essais critiques. Paris: Seuil, 1964. Disponível em <https://bibliotecadafilo.files.wordpress.com/2013/10/barthes-aestrutura-dos-fait-divers.pdf>. Acesso em 12 de dezembro de 2016.

BLANCHARD, Pascal; VEYRAT-MASSON, Izabelle. Introduction. In: BLANCHARD, Pascal; VEYRAT-MASSON, Izabelle. Les guerres de mémoires: la France et son histoire Enjeux politiques, controverses historiques, stratégies médiatiques. Paris: Éditions La Découverte, 2008a, p. 15-49.

BLANCHARD, Pascal; VEYRAT-MASSON, Izabelle. Introduction. Les Guerres de mémoires: un objet d'étude, au carrefour de l'histoire et des processus de médiatisation. HERMÈS: Revue de I'Institut des Sciences de la Communication du CNRS (ISCC), n. 52, p.13-22, 2008b. Les guerres de mémoires dans le monde.

CAETANO, Maria do Rosário (Org.). Alguma solidão e muitas histórias: a trajetória de um cineasta brasileiro, ou, João Batista de Andrade: um cineasta em busca da urgência e da reflexão. São Paulo: Imprensa oficial do Estado de São Paulo, 2004.

CAVALCANTE, Alcilene. A representação do passado nas telas: os discursos históricos em filmes de Bemberg e Yamasaki. In: AMANCIO, Tonico (Org.). Argentina-Brasil no cinema: diálogos. Niterói: Editora da UFF, 2014, p. 57-77.

CAVALCANTE, Alcilene. A lesbianidade nas telas brasileiras da transição democrática: o protagonismo de amor maldito, de Adélia Sampaio. Revista Eletrônica

Documento/monumento, v. 18, p. 142-155, 2016. Edição Especial: Relações de Gênero e saberes: mulheres, história e novas narrativas. Disponível em:

http://www.ufmt.br/ndihr/revista/. Acesso em: 20 de janeiro de 2017.

CORREIO BRASILIENSE, Brasília, 10 de maio de 1983.

DIDI-HUBERMAN, Georges. Diante do tempo. Trad. Alberto Pucheu. Revista Polichinelo. 21 de março de 2011. Disponível em: www.revistapolichinelo.blogspot.com.br/2011/03. Acesso em 24 de janeiro de 2017.

FERREIRA, Jonatas; AMARAL, Aécio. Memória eletrônica e desterritorialização. Política e Sociedade. n. 4, p. 137-166, abril de 2004. 
FERRO, Marc. O conhecimento histórico, os filmes, as mídias. Revista Eletrônica O Olho da História, 2004. Disponível em: <www.oolhodahistoria.ufba.br>. Acesso em 10 de janeiro de 2017.

FERRO, Marc. Regard sur les guerres de mémoires dans le monde. HERMÈS: Revue de I'Institut des Sciences de la Communication du CNRS (ISCC), n. 52, p.9-12, 2008. Les guerres de mémoires dans le monde.

FICO, Carlos. Prezada Censura: cartas ao regime militar. TOPOI: Revista de História, Rio de Janeiro, v. 5, p. 251-286, 2002.

FICO, Carlos. Versões e controvérsias sobre 1964 e a ditadura militar. Revista Brasileira de História. São Paulo, v.24, n.47, p.29-60, 2004.

FICO, Carlos.; ARAUJO, Maria Paula; GRIN, Monica (Orgs). Violência na história: memória, trauma e reparação. Rio de Janeiro: Ponteio, 2012. p. 25-38.

FOLHA DE SÃO PAULO, São Paulo, 27 de maio de 1980.

FOLHA DE SÃO PAULO,16 de maio de 1982.

FRANÇA, Andréa. A reencenação no cinema documentário. Matrizes, ano 4, n. 1, p.149161, jul./dez., 2010.

FILMER le passe: Les traces et la mémoire; No pasaran! Albulll souvenir. Paris, L' Harmattan, 2003.

GAZETA DE VITORIA, Vitória, 31 de julho de 1986

HUYSSEN, Andreas. Seduzidos pela memória: arquitetura, monumentos, mídia. Rio de Janeiro: Aeroplano, 2000.

HUYSSEN, Andreas. Culturas do passado-presente: modernismos, artes visuais, políticas da memória. Rio de Janeiro: Contraponto: Museu de Arte do Rio, 2014.

LAGNY, Michèle. Imagens audiovisuais e história do tempo presente. Tempo e Argumento. Florianópolis, v. 4, n. 1 p. 23-44, jan./jun. 2012.

NEVES, Frederico de Castro. Armadilhas nordestinas: o homem que virou suco. In SOARES, Mariza de Carvalho; FERREIRA, Jorge (Orgs.). A história vai ao cinema. Rio de Janeiro: Record, 2001 
NORA, Pierre. Entre a memória e a história: a problemática dos lugares. Trad. Yara Khoury. In: Projeto História: Revista do Programa de Estudos Pós-Graduados em História e do Departamento de História da PUC/SP. São Paulo: PUC SP, 1981.

NORA, Pierre. L'événement monstre. Communications, n. 18, p. 162-172, 1972.

O Estado de São Paulo, São Paulo, 13 de novembro de 1983.

O Estado de São Paulo, São Paulo [19--].

O GLOBO, Rio de Janeiro, 11 de abril de 1984

Pasta João Batista de Andrade/CEDOC - Centro de documentação da FUNARTE POLLACK, Michael. Memória, esquecimento e silencio. Estudos Históricos, Rio de Janeiro, v.2. n.3, p. 3-15, 1989.

RAGO, Margareth. A prostituição ontem e hoje. In: GRILLO, José Geraldo; GARRAFONI, Renata; FUNARI, Pedro Paulo, Sexo e violência. São Paulo: Annablume, 2011, p. 211-225.

RAMOS, Alcides. O cinema de João Batista de Andrade e a resistência à ditadura militar brasileira (1964-1985). Perseu: História, memória e política. São Paulo: EPA, n.1, ano 1, p. 315-335, 2007.

REIS FILHO, Daniel Aarão. Ditadura e democracia no Brasil: do golpe de 1964 à constituição de 1988. Rio de Janeiro: Zahar, 2014.

RIDENTI, Marcelo. Resistência e mistificação da resistência armada contra a ditadura: armadilha para os pesquisadores. 40 anos do golpe: ditadura militar e resistência no Brasil. Rio de Janeiro: 7Letras, 2004, p. 140-152.

ROLLEMBERG, Denise. “Esquecimento das memórias”. In: João Roberto Martins Filho (Org.). $O$ golpe de 1964 e o regime militar. São Carlos: Ed.UFSCar, 2006, p. 81-91.

ROUSSO, Henry. Face au passé: essais sur la mémoire contemporaine. Paris, Belin, 2016a

ROUSSO, Henry. A última catástrofe: a história, o presente, o contemporâneo. Trad. Fernando Coelho, Fabrício Coelho. Rio de Janeiro: FGV Editorial, 2016b

ROUSSO, Henry. Vers une mondialisation de la mémoire. Vingtième Siècle: Revue d'Histoire, n. 94, p. 3-10, 2007/2 
SOBRINHO, Gilberto. João Batista de Andrade, o cinema de intervenção e a voz política: corpos, dramatização e encenação do real. In: BEATRIZ, Dilma; ROCHA, Juliano; SOBRINHO, Gilberto; ROSSINI, Miriam de Souza (Orgs.) Televisão: formas audiovisuais de ficção e documentário. Palhoça: Ed. Unisul, 2013, p 12-26.

STAM, Robert. Multiculturalismo tropical: uma história comparativa da raço na cultura e no cinema brasileiros. São Paulo: EDUSP, 2008.

XAVIER, Ismail. O momento do golpe, as primeiras reações e o percurso do cinema de oposição no período de ditadura. In: ALONSO, Angela; DOLHNIKOFF, Miriam (Orgs). 1964: do golpe à democracia. São Paulo: Hedra, 2015, pp. 213-232.

\section{Filmografia de João Batista de Andrade (documentários e ficção)}

Doramundo. Direção: João Batista de Andrade. Produção: Raiz Produções

Cinematográficas; Embrafilme - Empresa Brasileira de Filmes S.A. São Paulo, 1977, 35mm, COR, 85min.

Caso Norte. Direção: João Batista de Andrade. Produção: Rede Globo; Raiz Produções cinematográficas. São Paulo, $16 \mathrm{~mm}$, COR, 38min.

Liberdade de Imprensa. Direção: João Batista de Andrade. Produção: Grêmio da Faculdade de filosofia da USP - Jornal Amanhã (UNE) - São Paulo, 1967, 16mm, BP, 24minzoseg.

O homem que virou suco. Direção: João Batista de Andrade. Produção: Raíz Produções Cinematográficas; Embrafilme - Empresa Brasileira de Filmes S.A.; Governo do Estado de São Paulo - Secretaria de Cultura (Polo de cinema - SP). São Paulo, 1979/1980, 35mm, COR, 97min.

A próxima Vítima. Direção: João Batista de Andrade. Produção: Raiz Produções cinematográficas; Taba filmes; Embrafilme - Empresa Brasileira de Filmes S.A.. São Paulo, 1982, 35mm, COR, 91min.

Vlado - 30 anos depois. Direção: João Batista de Andrade. Produção: Oeste filmes. São Paulo, 2005, 85 min. 35mm, COR, 90min.

Wilsinho Galileia. Direção: João Batista de Andrade. Produção: Rede Globo; Raiz Produções cinematográficas. São Paulo, 1978, 16mm, COR, 62min. 
Recebido em 30/04/2017 Aprovado em 21/08/2017

Universidade do Estado de Santa Catarina - UDESC Programa de Pós-Graduação em História - PPGH Revista Tempo e Argumento Volume 09 - Número 21 - Ano 2017 tempoeargumento@gmail.com 